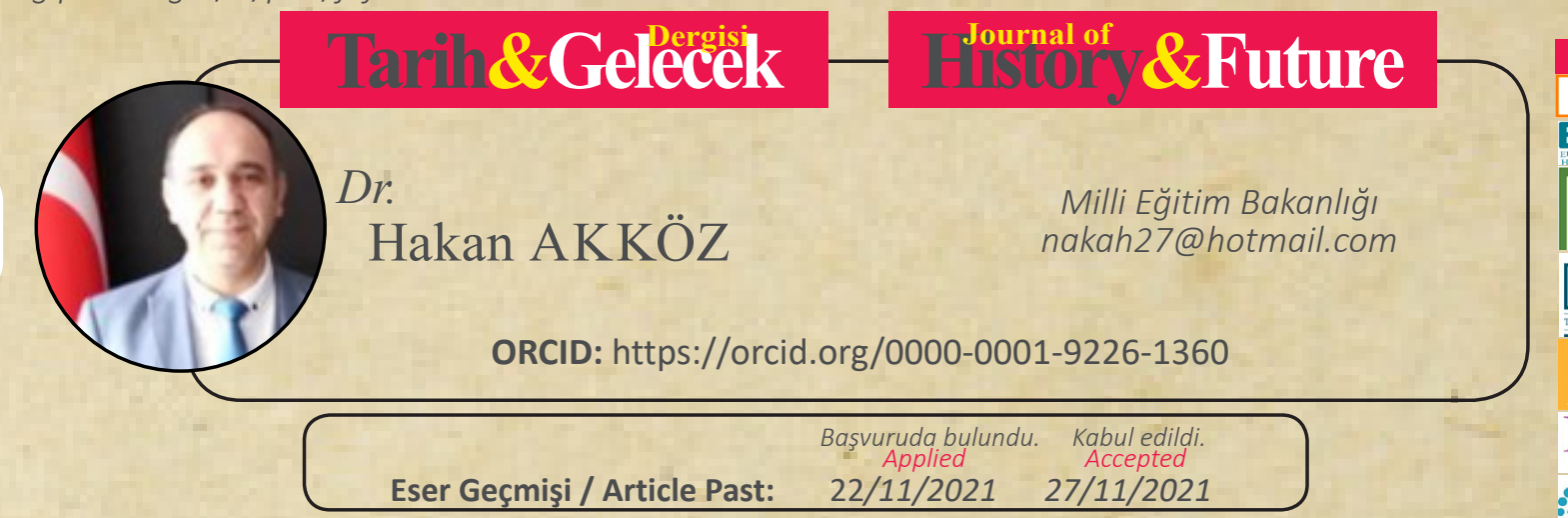

Indexed by ERIHPILUS

Araştırma Makalesi DOI: http://dx.doi.org/10.21551/jhf.1027273 Research Paper 2. $\begin{gathered}\text { Academic } \\ \text { Resource } \\ \text { Index } \\ \text { ResearchBib }\end{gathered}$ RIISAM

Orjinal Makale / Orginal Paper

\title{
Yeniçağda Osmanlı Devletinde Yeniçerilerin Siyasal Ve Sosyal Etkinliği (Fatih, Bayezid, Yavuz Sultan Selim, Kanuni Sultan Süleyman Dönemleri)
}

\author{
The Political and Social Activity of the Janissaries in the \\ Ottoman State in the Early Modern Age (Fatih, Bayezid, Yavuz \\ Sultan Selim, Süleyman The Magnificient Era)
}

$\ddot{O} z$

Osmanlı tarihinde önemli bir yeri olan askeri teşkilat ve o teşkilatın insan kaynağını sağlayan yeniçeri ocağı olmuştur. Yeniçeri ocağının kuruluş tarihinin tam olarak bilinmediği kabul görmüş bir çıkarımdır. Önceleri savaş esirlerinden devşirilen yeniçeriler daha sonra Fatih Sultan Mehmet döneminde Fethedilen topraklardaki Hristiyan çocukların sistemli bir şekilde devşirilmesi ile yeniçeri ocağının kurumsallaşması sağlanmıştır. Yeniçeri ocağının kuruluşundan itibaren kanuni sultan Süleyman dönemine kadar yararlıklar sağladığı, disiplinli bir asker ocağı olduğu bilinmektedir. Fakat Kanuni Sultan Süleyman döneminde ve sonrasında Yeniçeri ocağında bozulmaların, disiplinsizliğin baş gösterdiği bilinmektedir. Hatta sadece cülus bahşişini beğenmediği ya da Ulufeyi arttırmak için dahi isyan çıkarmışlardır. Devlet adamlarının ve de bazen padişahların değişmesine neden olmuşlardır.

Bu çalışmada, öncelikle Yeniçeri ocağının kuruluşundan itibaren geçirdiği aşamalara değindikten sonra özellikle Fatih Sultan Mehmet döneminde ve sonrasında yeniçeri eksenindeki olayları ve isyanları ele almaya çalışacağız. Bu konuda alanda yapılan çalışmaların çoğunluğu yeniçeri isyanlarına ve devlet içinde otorite olma çabalarına yoğunlaşmıştır. Yeniçeri isyanlarının Buçuktepe isyanı ile başladığını söyleyebiliriz. Zamanla devlet içinde politik bir güce sahip olmaya başlayan yeniçeri devlet adamlarının hatta padişahların değişmesinde ve Osmanlı Devleti politik hayatında etkili bir rol oynamıştır. Kanuni Sultan Süleyman'ın Viyana seferinde başarısız olmasında da yeniçerilerin etkisi vardır.

Anahtar Kelimeler: Yeniçeri, İsyan, Yeniçağ, Buçuktepe, Ordu 


\section{Abstract}

It was the military organization, which had an important place in the Ottoman history, and the Janissary corps, which provided the human resources of that organization. It is an accepted conclusion that the establishment date of the Janissary corps is not known exactly. The janissary corps was institutionalized with the systematic recruitment of the janissaries, who were recruited from the prisoners of war, and then the Christian children in the conquered lands during the reign of Mehmet the Conqueror. It is known that the Janissary corps was a disciplined military corps that provided benefits from its establishment until the reign of Süleyman the Magnificent. However, it is known that corruption and lack of discipline started in the Janissary corps during and after the reign of Süleyman the Magnificent. Even they did not like the culus tip or they even rebelled to increase the Ulufe. They caused statesmen and sometimes sultans to be changed.

In this study, first of all, we will try to deal with the events and rebellions in the axis of the Janissaries, especially during and after the period of Fatih Sultan Mehmet, after mentioning the stages that the Janissary corps went through since its establishment. Most of the studies on this subject focused on the janissary revolts and the efforts to become an authority in the state. We can say that the Janissary revolts started with the Buçuktepe revolt. Janissaries, who started to have a political power in the state over time, played an effective role in the change of statesmen and even sultans and in the political life of the Ottoman State. The janissaries also played a role in the failure of Suleiman the Magnificent in his Vienna campaign.

Key Words: Janissaries, Revolt, Early Modern Age, Buçuktepe, Army

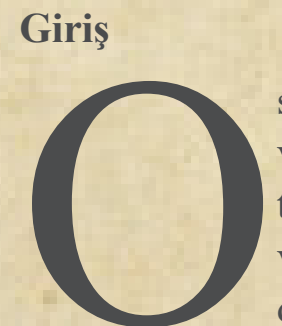

smanlı Devleti'nin çağdaşı devletlere göre güçlü bir siyasi teşkilat olarak var olmasının arkasında yatan en önemli sebep düzenli ve disiplinli bir ordu teşkilatına sahip olmalarıdır. Kuruluş döneminde kurulan ve temeli tımar ve kul sistemi olmak üzere iki farklı sisteme dayandırılan askeri teşkilat, doğuda ve bilhassa batıda Osmanlı hanedanının temel dayanağı olmuştur ${ }^{1}$. Osmanlı devleti kurduğu askeri sistemin sayesinde giriştiği fetih hareketlerinden başarılı çakmış ve savaş alanlarında çoğu zaman üstünlüğü elinde bulundurmuştur. Bu başarıyı yeniçeri ordusunun ve temelde ona bağlı diğer ocakların nizamı ve disiplinine bağlamayla beraber Kanuni Sultan Süleyman dönemine kadar Padişahların ve devlet adamlarının dirayetli duruş ve yönetim anlayışından kaynaklandığını söyleyebiliriz.

Yeniçeri Ocağı'nın kuruluşu tarihi tam olarak bilinmemektedir. Ayrıca yeniçeri ocağı belirli bir süreç içerisinde gelişip oluştuğu düşünülmektedir. Osmanlı devletinin Orhan Bey döneminde (1324-1362) yeni fetihler yapmak istemesinden dolayı daha fazla askere ihtiyaç duymuştur. Bu asker ihtiyacını karşılamak için savaş esirlerinden asker devşirmeye başvurduğu genelde kabul gören bir yaklaşımdır. Savaş esirlerinden oluşturulan askerler (yeniçeri) kullanılmaya başlamadan

1 İsmail Katg1, Osmanlı Devleti’nde Tipik Bir Askeri Ayaklanma Örneği: Viyana'dan Dönüş ve 1687 İsyanı, VAKANÜVIS- Uluslararası Tarih Araştırmaları Dergisi/ International Journal of Historical Researches, Y11/Vol. 5, Sayı/s,762,No. 2, Güz/Fall ISSN: 2149-9535 / 2636-7777, 2020 
önce Müslüman halktan oluşturulan asıl mesleği askerlik olmayan, normal zamanda kendi işi ile meşgul olan savaş zamanı ücret alan birliklerde görülen düzensizlik ve disiplinsizlik bu ihtiyacı doğurmuştur denilebilir. Bu uygulamayı doğru bulmayanlar da olmuştur. Orhan Bey döneminde yeniçeri sayısının 1000 kadar olduğu kaydedilmiştir. Bu askerler maaşlı ve sürekli askerlik hizmetinde olması düşünülen askerlerdir ki, Sultan I. Murad döneminde (1362-1389) Gelibolu'da Acemi Ocağı'nın kurulduğu ve bunun Kazasker Çandarlı Kara Halil ile Molla Rüstem'in yönlendirmesiyle gerçekleştiği genelde tekrarlanan bilgiler arasındadır ${ }^{2} .1453$ yilında İstanbul'u fethiyle beraber bu kurumun da klasik hususiyetlerine kavuştuğu aşikârdır. Devşirme yöntemi kullanılarak oluşturulan ve bahsedilen tarihe kadar Osmanlı ordusu içinde küçük bir grubu teşkil eden yeniçerilerin, bu tarihten sonra sayı ve etkileri artmaya başlamıştır. XV. yüzyılın ilk yarısından itibaren işlerlik kazanan devşirme sistemi ile Hıristiyan teb'a arasından yeniçeri olacak olan 8 ila 18 , hatta 20 yaşları arasındaki sıhhatli ve gürbüz çocuk ve gençler, yeniçeri ağası tarafından seçilir ve devşirilirdi ${ }^{3}$. Fiziksel olarak bozukluk ve rahatsızlı̆̆ bulunan çocuklar devşirilmezdi. Ayrıca sadece fiziksel sağlık tek ölçüt değildi mesela; Çok uzun boylu veya çok kısa boylular çocuklar da devşirme için alınmaz, orta boylu çocuklar tercih edilirdi. Genel olarak vücudunda arızası olmayan vücut oranları dengeli olan sağlıklı çocuklar devşirilmek üzere alıyorlardı. Bunun yanı sıra Köse, kel, doğuştan sünnetli olanlar devşirilmezdi. Evli olanlar, köylerde veya şehirlerde devlet hizmetinde olanların (Kethüda vb.) çocukları devşirilmezdi. Çoban ve sığırtmaç olanlar, Türkçe bilenler, sanatkârlar, şehirde yaşayanlar, İstanbul'a gelmiş olanlar da devşirilmezdi. Bunlardan da anlaşılacağı gibi henüz gözü açılmamış, eğitilmeye müsait, saf ve temiz çocuklar tercih ediliyordu. Evli, çoban, sığırtmaç, resmi dil olan Türkçeyi öğrenmiş olan, sanat sahibi, şehirliler, İstanbul görmüş olan çocuklar gözü açılmış olduğu için eğitilmeye müsait değildi ${ }^{4}$.

Kapıkulu ocaklarının önemli bir parçası olan ve tamamen padişaha bağlı ve padişaha karşı sorumlu bir askeri birlik olarak teşekkül eden yeniçeriler, hem merkezde padişahın korumalığı gibi önemli bir görevi üstlenmiş hem de özellikle fetihlerde önemli bir askeri güç olarak kullanılmıştır. Savaşlarda at üzerinde bulunan ve ok, yay, kalkan ve k1liç gibi daha çok geleneksel nitelikte savaş aletleri kullanan tımarlı sipahilerin aksine yeniçerilerin, tüfek gibi ateşli silahların kullanımında görevli ve usta olmaları bilahare önemlerinin giderek artmasına sebep olacaktır ${ }^{5}$. Osmanlı paralı asker sınıfını teşkil eden yeniçeriler ulûfe adı verilen maaşlarını üç ayda bir veziriazamın huzurunda dîvân-1 hümâyunda alırlardı. Ayrıca yeniçerilerin tek geliri bu değildi. Yaka akçesi ve keman akçesi gibi adlarla ödemeler alıyorlardı. ${ }^{6}$ Yeniçeri Ocağı'nın Komutanına "Yeniçeri Ağası" denirdi. Yeniçeri Ağası protokolde veziriazamdan önce gelirdi çünkü yeniçeriler doğrudan padişaha bağlıydı. Bu güç sayesinde padişah uç beylerinin nüfuz ve etkinliği dengelemiştir. Yeniçeri ağalarından XVI. ve XVII. yüzyıllarda veziriazam olanlar da olmuştur. Üç ayda bir "Ulufe" adı verilen maaşlarını alan yeniçeriler yılda bir kez de elbise alırlardı?

2 Kemal Beydilli, "YENIÇERI", TDV İslâm Ansiklopedisi, https://islamansiklopedisi. org.tr/yeniceri $(10.11 .2021)$

3 Ahmet Elibol, Yeniçeriler ve iktidar Bağlamında Osmanlı Sisteminin Dönüşümü. Gazi Akademik Bakış 3:s,22., 2009.

4 Abdullah Demir, , "Osmanlı Devletinde Devşirme Sistemi”, Uluslararası Sosyal Bilimler Dergisi, C,I,S,1,s,23. 2017,Sivas

5 Elibol,a.g.e,2009,s,23

6 Fatma Kaytaz, ,Osmanlı Askerî Teşkilatı Hakkında Bilinmeyen Bir Eser "Yeniçeri Ocağına İlişkin Bir Risale" (Değerlendirme Ve Metin),Tarih Dergisi,S,57,s,51, 2013

7 Mehmet Ali Ünal, Osmanlı Müesseseleri Tarihi, Fakülte Kitabevi, s. 69,-71, 2010, Isparta 
İbni Batuta devrinde, Osmanlı akçesinin bir gümüş dirheme nisbeti 13/40 idi. Buna göre, 2 akçe alan bir yeniçeri 65/100 dirhem gümüş alıyordu. 1510 'da bir dirhem gümüş dört akçeye satıldığına bakılınca, akçenin gümüş nisbeti \% 25 olduğu görülür. Bu tarihte, ortalama, bir ulufe 4 akçe olduğuna göre ele geçen gümüş miktarı \% 35 artmış demektir. XVI. yüzyılın son yarısında akçenin gümüş nisbeti \% 20 idi. Bu sırada orta bir ulufe 7 akçe idi ve bir yeniçeri 1,4 dirhem gümüş alıyordu. 1585 'de akçenin gümüş nisbeti \% 12,5 a indirildi. Orta ulûfeliye 8 akçe verilmekte idi. Bu bir miktar dirhem gümüş demektir. Nihayet 1595 de, 1 dirhem gümüşten 9,5 akçe kesildiğinden, 9 akçeli bir yeniçeriye bir dirhemden az eksik bir gümüş veriliyordu. Görülüyor ki, ilk yeniçeriye verilen gümüşe nazaran XVI. yüzyılın sonundaki bir yeniçerinin aldığı gümüş fazlalığı ancak \% 25 'dir. Hâlbuki ilk yeniçeri bir akçeye iki buçuk kilo et alabiliyordu. 1582'deki bir yeniçeri ise aynı akçe ile ancak 375 gram et alabilmekte idi ${ }^{8}$.

Yeniçeri isminin kökeni ise; Hacı Bektaş Veli’nin Orhan Gazi döneminde düzenlediği ve askerleri kabul ederek onlara dua etmesi, başlık giydirmesi ve "Yeniçeri" ismini vermesiyle başlatılmıştır. Rivayete göre, Orhan Gazi, Sulucakaraöyük’te ikamet eden Hacı Bektaş Veli’nin yanına gitmiş, ihdas ettiği yeni askerin ismini koymasını ve bu askerlere hayır dua etmesini talep etmiştir. Bunun üzerine Hacı Bektaş Veli, askerlerden birini yanına çağırarak cübbesinin bir kolunu askerin başının üzerine koymuş ve "Bu yeni askerin ismi Yeniçeri olsun. Cenab-1 Hak yüzlerini ak, pazılarını kuvvetli, kılıçlarını keskin, oklarını mühlik, kendilerini galip buyursun" diye dua etmiştir ${ }^{9}$. Yeniçeri ocağı kurulduğu günden başlayarak Ocağa hâkim olan katı disiplin ve mutlak itaat Yeniçeri Ocağını devrinin en mükemmel ordusu kılmıştı. Fakat bu üstün durum pek uzun sürmemişti. 16. yüzyılın ortalarından itibaren durum tersine döndü. Yeniçeri ocağında bozulmalar baş gösterdi ${ }^{10}$ Yeniçeri ve Bektaşi dergâhı arasındaki ilişkinin 18. Yüzyılda nasıl algılandığını, İlber Ortaylı şöyle izah etmektedir; "Bektaşîlerin yeniçerileri kışkırttığı ve fesat yarattıkları da ortaya atılan iddialardı, ama bu arada yeni rejimin himaye ettiği ve bu alanda söz sahibi olan Nakşibendîlerin aynı garezi Bektaşîler yanında Melâmîlere de yönelttiği görülmektedir. Kuşkusuz bu gerilimin kökleri daha eskiye gitmektedir. Nitekim 18. asır yazarlarından Vassaf Hüseyin in Sefinetü'l-Evliya'sında birtakım olaylar ve yorumlarla Bektaşîlerin zındıklığının ispatına gayret edildiği görülmektedir ${ }^{11}$."

Yeniçeri Ocağı I. Murad zamanında 1000 kişilik bir birlik halinde kurulmuştur. Yıldırım Bayezid döneminde artan bu sayı II. Murad döneminde 3000-4000, Fatih Sultan Mehmed zamanında ise 8000 ile 12000 bin ve Kanuni zamanında 12000-14000'i bulmuştur. XVI. yüzyılın sonlarına doğru uzun süren savaşlar ve değişen savaş tekniklerine paralel olarak yeniçeri ordusu 40000’i geçmiştir. Sayısı artan ve güçlenen Yeniçeri ordusunun siyasi ağırlığı artmış ve iktidar mücadelesine karışmışlardır ${ }^{12}$.

8 Mustafa Akdağ, "Yeniçeri Nizamının Bozulması", Ankara üniversitesi DTCF Dergisi,C,5,S,3,ss, 291-322, Ankara,1947

9 Fahri Maden, Yeniçerilik-Bektaşilik İlişkileri Ve Yeniçeri isyanlarında Bektaşiler, Türk Kültürü ve Hacı Bektaş Velî Araştırma Dergisi / 2015 / 73s,175

10 Ahmet Yüksel, Yeniçeri Ocağı, Bozulma ve Casusluk, Journal of History Studies,s,272 , (Haziran) 2017

11 İlber Ortaylı, Osmanlı'da Milletler Ve Diplomasi,Türkiye İş Bankası Kültür Yayınları,s,148, 2008,stanbul.

12 Mehmet Ali Ünal, Osmanlı Müesseseleri Tarihi, Fakülte Kitabevi, s. 69,-71, 2010, Isparta 


\section{Fatih Sultan Mehmed Dönemi}

11. Murad 1444'te Macarlarla ve Karamanoğulları ile barış antlaşmaları imzalamıştı, bu anlaşmayı yaparak devleti hem batıda hem de doğuda emniyete almış oldu. Daha sonra hayatta kalan tek oğlu Şehzade Mehmed lehine tahttan çekilmeyi tercih etmişti,ve Manisa'ya gitmişti. 11. Mehmed o sırada henüz on iki yaşlarında idi. Divan-1 Hümayun ise Veziriazam Çandarlı Halil Paşa, Rumeli Beylerbeyi Hadım Şehabeddin Paşa, Zağanos Mehmed Paşa, Saruca Paşa ve Kazasker Molla Hüsrev'den oluşuyordu. Fakat 11. Murad'ın Manisa günleri çok uzun sürmedi. Macarlar Osmanlı tahtına küçük yaşta birinin geçmesini fırsat bilerek, Karamanoğlu'nun da kışkırtmasıyla, on yıllığına imzalanmış olan Segedin Antlaşmasını (12 Temmuz 1444) bozarak Osmanlı Devleti'ne savaş açtılar (1 Eylül 1444) ${ }^{13}$

Macarlarla başta papalık olmak üzere Eflak ve Sırp prenslikleriyle beraber Alman ve İtalyanlar da katıldı ve böylece Avrupa'da büyük bir Haçlı kuvveti toplandı. Haçlıların Bulgar topraklarına kadar gelerek, buraları yağmalayarak Varna'ya kadar gelmişlerdi. Bunun üzerine, Osmanlı vezirleri II. Mehmed'in başkanlığında toplanıp Sultan Murad'ı tekrar tahta çıkarmaya karar verdiler. Sultan Murad bir rivayete göre Edirne'de tahta çıkmış, daha doğru bir başka rivayete göre ise sadece Osmanlı ordusuna kumanda etmiş, 11. Mehmed Varna Savaşı sırasında padişahlığını korumuş ve Halil Paşa ile birlikte Edirne muhafazasında kalmıştır. Haçlı kuvvetlerine karşı kazanılan Varna Zaferi'nden (10 Kasım 1445) sonra Sultan Murad bir süre Edirne'de kalmış ve tahta geçmemiştir. Çünkü bu sırada İslam ülkelerine gönderilen bazı fetihnameler II. Mehmed adına yazılmış, gelen cevap nağmeler de yine onun adına gelmiştir ${ }^{14}$.

$1445^{\prime}$ 'li yıllarda Edirne'de II. Murad ve oğlu Sultan Mehmed'i tutan devlet adamları arasında büyük bir anlaşmazlık vardı. Bazı devlet adamları Sultan II. Murad'ı tutarken, bazıları Sultan II. Mehmet'i tutuyordu; Veziriazam Çandarlı Halil Paşa ve yeniçeriler Osmanlı tahtında Sultan Murad'1 görmek isterken, Şehabeddin, Zağanos ve Saruca Paşa gibi vezirler ise 1l. Mehmed'i tahtta görmek istiyorlardı. Çandarlı'nın daha barışçıl bir politika izlemek istemesine karşın diğer paşalar Sultan II. Mehmed'i fetihler konusunda, özellikle de İstanbul'un fethi konusunda cesaretlendiriyorlardı. Bu sebeple II. Murad oğluna ve onu cesaretlendiren vezirlere bir uyarıda bulunmak zorunda kalmıştı. $\mathrm{Bu}$ arada Halil Paşa 11. Murad'ı tekrar Osmanlı tahtına geçirmek için planlar yapıyordu. Hatta veziriazamın genç hükümdarı kolayca kandırarak Varna Zaferinin ardından nezaketen babasına taht teklifinde bulundurduğundan bile söz edilir. Güya II. Murad bu teklifi nasıl olsa kabul etmeyecek ve yine 11. Mehmed Osmanlı tahtında kalacaktı. Bir başka rivayete göre ise II. Murad Varna Seferi'nden veya bir avdan dönerken askerle görüşmüş ve onların kendisini istediklerinden emin olduktan sonra ikinci defa saltanatı kabul etmiştir ${ }^{15}$.

Goodwin' in ifadesiyle yeniçerilerin varlığı devlete hem destek vermiş hem de başlangıçtan beri, sürekliliğine yönelik tehdit oluşturmuştur. Nihayet Sultan II. Mehmet'in hükümdarlığının ilk döneminde 1446 Buçuktepe İsyanı ile başlayan askeri isyanlar, yeniçeri ocağının kaldırıldığı 1826 tarihine değin adeta gelenek halini almış; bu uzun süreç boyunca hemen hemen her padişah bu tür

15 Özcan,a.g.e,1992,ss,343-344 
girişimlerle karşı karşıya gelmiştir ${ }^{16}$.

Il. Mehmed'in birinci saltanatından çekilmesinin asıl sebebi olan ve tarihlere Buçuktepe Vak'ası olarak geçen olay da yine bu sırada Edirne'de çıkmıştır. Osmanlı tarihinde görülen bu ilk yeniçeri ayaklanmasının zahiri sebebi, Osmanlı para birimi olan akçenin ayarının düşürülmesidir. Çünkü bu ilk para ayarlaması askeri ve piyasayı zarara sokmuştu. Kaynakların bildirdiğine göre aylardır maaşlarını alamayan yeniçeriler paranın değerinin düşürülmesinden rahatsız olmuşlar ve isyan çıkarmışlardır. Rumeli Beylerbeyi Hadım Şehabeddin Paşa'nın evini yağmalamışlar, bu arada Şehabeddin Paşa 11. Mehmed'in sarayına sığınarak canını zor kurtarabilmiştir. Yeniçeriler daha sonra şehrin doğusunda ki tepeye çekilmişlerdir. İsyan, yeniçeri maaşlarına yarım (buçuk) akçe zam yapılarak yatıştırılmış ve o zamandan beri bu tepe Buçuktepe adıyla anılmıştır. İsyancılar bu şekilde yatıştırılmışsa da asker artık genç padişahtan yüz çevirip babasının hükümdar olmasını istemiştir. ${ }^{17}$

Öte yandan Buçuktepe Vak'ası'nın II. Mehmed'in tahtta geçmesini engellemek için Çandarlı Halil Paşa'nın tertiplediği düşünülmektedir. Çünkü bu olayda doğrudan Çandarlı'nın baş rakibi ve genç padişahın birinci adamı Şehabeddin Paşa hedef alınmış, böylece Sultan 11. Mehmed'in tahtı tehlikeye düşmüş ve Edirne'de bir iktidar boşluğu doğmuştur. Bunun üzerine Çandarlı'nın gizlice gönderdiği haberle 1446'da Edirne'ye gelen 11. Murad yeniden Osmanlı tahtına çıkmış, Şehzade Mehmed de yanında güvenilir adamları olduğu halde Manisa'ya dönmüștür. Osmanlı tarihinde Buçuktepe Vak'ası ile asker ilk defa politikaya alet edilmiş ve bundan böyle yeniçerilerin nüfusu sürekli artmıştır. Edirne'de halen aynı adı taşıyan mahallenin biraz dışında kalan Buçuktepe mevkiinde şehir mezarlığı bulunmaktadır ${ }^{18}$.

Fatih Sultan Mehmed'in İstanbul'u fethederek (1453) tamamen iktidar sahibi olması ile Çandarlı Halil Paşa ve Yeniçeri Ocağı'nın üstünlüğü sona erdi. Yeniçeri Ocağı, 12 bin kişi mevcudu ile Osmanlı İmparatorluğu'nun 1481 ve 1566 yılları arasında Avrupa'nın en güçlü orduları arasında yer almıştır. Osmanlı Devleti bu dönemde Avrupa denge politikasında belirleyici konumda yer alarak Avrupa Devletler Sisteminin güç sahibi önemli bir üyesi halindedir.

Ancak bu durum Avrupa'da Malta ve Lepanto mağlubiyeti ile Osmanlı aleyhine değişerek Avusturya'ya ( Alman İmparatorlu'na) karşı yeniçeri ordusu ile yapılan uzun savaşta (1593-1606) Batı Savaş Teknolojisi'nin üstünlüğü ile bozulmuştur ${ }^{19}$.

Fatih Sultan Mehmet'in tahta geçtikten sonra çözmek için yola düştüğü konu Karamanoğlu meselesiydi. Karamanoğlu beyliğinin üzerine ordu ile gitti fakat Karamanoğulları Taşili’ne çekilmişlerdi. Sultan II. Mehmet bunun üzerine Edirne'ye dönmeye karar verdi. Yeniçeriler yolda, daha önce olmayan uygulamayla, bunun padişahın ilk seferi olduğunu söyleyerek bahşiş dağıtmasını istediler. Daha Önce tahtan indirip babasının dönmesini isteyen yeniçeriler kendilerine

16 İsmail Katg1,Osmanlı Devleti’nde Tipik Bir Askeri Ayaklanma Örneği: Viyana'dan Dönüş ve 1687 İsyanı, Vakavinüs- Uluslararası Tarih Araştırmaları Dergisi/ International Journal of Historical Researches, Y11/Vol. 5, Say1/No. 2, Güz/Fall 2020 ISSN: 2149-9535 / 2636-7777,ss,762-763.

17 Abdülkadir Özcan, "Buçuk Tepe Vak’ası”, TDV İslam Ansiklopedisi, s,343 -344,İstanbul,1992

18 Özcan,a.g.e, 1992,s,344.

19 Halil İnalcık, Kuruluş ve İmparatorluk Sürecinde Osmanlı, Timaş Yayınları, s. 114, 2011, İstanbul 
ulufe dağıtılmasını istiyorlard ${ }^{20}$. Bu bir anlamda padişaha ve devlete isyan başlatma isteğiydi.

Yeniçerilerin tarihte ilk isyan girişimi yukarıda da bahsi geçen, 1444 yılında gerçekleşen Buçuktepe isyanıdır. İlk darbe izi Yavuz Sultan Selim'in yeniçerilerle anlaşarak babasını tahtan indirmesidir. Padişah değiştirdikleri ilk darbe, 17. Yüzyılda, Genç Osman'a karşı gerçekleştirmiştir. $\mathrm{Bu}$ isyanlar 1826 yılında yeniçeri ocağının kapatıldığı tarihe kadar devam etmiştir ${ }^{21}$.

\section{II. Bayezid Dönemi}

Fâtih Sultan Mehmed'in 3 Mayıs 1481'de ölümünün ardından; II. Bayezid döneminde Fatih Sultan Mehmet'ten sonra tahta Cem sultanın geçeceği dedikoduları mevcuttu ${ }^{22}$. Taht varisi olarak Vezîriâzam Karamânî Mehmed Paşa' Şehzade Cem'in tarafında olsa da İstanbul muhafızı İshak Paşa ile Bayezid'in damatları Anadolu Beylerbeyi Sinan ve yeniçeri ağası Kasım'ın ise Şehzade Bayezid'i istedikleri bilinmektedir. Fâtih öldüğünde kapıcılardan Keklik Mustafa Bayezid'e gönderilirken Cem'e de haber yollanmıştır. Ancak Cem'e giden ulağın yolu kesilmiş, İstanbul'da baş gösteren karışıklıklarda Karamânî Mehmed Paşa öldürülmüş ve Bayezid taraftarı olan Bektaşi tekkelerinin ve onların çabasıyla yeniçerilerin de desteğini alarak tahta geçmişti. Yeniçeriler sokaklarda Bayezid lehine gösteriye başlamışlardı. Bir an önce gelmesi için Bayezid'e dâvetnâmeler gönderen İshak Paşa İstanbul'da bulunan oğlu Korkut'u babasına vekâleten tahta oturtmuştu. 21 Mayıs'ta İstanbul'a geçip babasının cenaze merasimine katılan Bayezid, Şehzade Korkut'tan saltanatı devralmıştır. Bayezid ilk olarak kapıkullarına üçer bin akçe cülûs bahşişi dağıttığı gibi yeniçeri ulûfelerini 5 akçeye çıkarmıştır. Yeniçeri Ocağı'nda “Ağa Bölükleri” denilen yeni bir sınıf oluşturularak ordu güçlendirilmek istenmiştir ${ }^{23}$.

Osmanlı devletinin önemli zaferler kazandığı döneminde yetişen büyük kumandanlardan olan Gedik Ahmed Paşa devşirmeden veya pençik esirlerindendi. Yeniçeri Ocağından yetiştiği rivayet edilen bu paşanın kesin olmamakla birlikte Arnavut olduğu tahmin edilmektedir. Gedik Ahmed Paşa ilk defa 146l'deki seferde beylerbeyi göreviyle karşımıza çıkmaktadır. 1474 senesinde Vezir-i Azamlık makamına tayin edilmiştir

Fatih'in ölümü üzerine Cem'e karşı yapılan harekâtta bulunmuş ancak karşıtları tarafindan Cem'in Suriye'ye kaçmasının kendisinin hoşgörüsü ile olduğu malumatı padişaha iletilmiş ve hapsettirilmiştir. Bu hususta Hamza Beyzade Mustafa Paşa'nın mühim tesiri olmuş; Bayezid'in Ahmed Paşa hakkındaki şüphesi artmıştır. Gedik Ahmed Paşa da kendi aleyhine hareket eden Mustafa Paşa'yı, kayın pederi İshak Paşa ile ittifak ederek padişaha öldürtmüşlerdir. Bu durumun farkından olan Bayezid ise daha sonra görülmüştür ki bu harekete karşı intikam almayı uygun bir

20 Yahya Başkan,'Osmanlı'da Çıkan İsyanların Öncüsü: Fatih Sultan Mehmet Dönemi Yeniçeri İsyanları",Osmanlı Payitahtında Siyasi Muhalefet Ve Protesto Kültürü (Ed:Yasemin Avc1,vd.),Libra Kitapçılık ve Yayınları, İstanbul, 2020.

21 Ahmet Deniz, Osmanlı Devletinde Yaşanan Darbe Ve İsyanların İktisadi AçIdan Analiz, Social Science Journal 5: 7146-7147, 2019

22 Gülay Yılmaz. Bektaşilik ve İstanbul'daki Bektaşi Tekkeleri Üzerine Bir İnceleme. Osmanlı Araştırmaları Dergisi XLV: ss,102-104. 2015.

23 Şerafettin Turan, II.Bayezid, TDV İslam Ansiklopedisi, 5. Cilt, s.234-237, 1992, İstanbul 
zamana bırakmıştır.

Bayezid, İskender Paşa'yı İstanbul muhafazasında bırakarak devlet erkaniyle ve bir kısım yeniçeriyle beraber Edirne'ye gitmiştir. Burada 18 Aralık 1483 tarihinde Yeni Saray’ da işret meclisinde eğlenip içildikten sonra orada bulunanlara hil'atler giydirilip ikram olunurken Gedik Ahmed Paşa'ya da siyah kaftan giydirilip öldürülmüştür. Gedik Ahmed Paşa 'nın öldürülmesi nedeniyle Edirne'deki yeniçeriler ayaklanıp Edirne Subaşı' nı öldürdülerse de hadise bastırılmıştır ${ }^{24}$. Gedik Ahmed Paşa'nın Edirne'de öldürülmesi İstanbul' da olası bir Yeniçeri ayaklanmasına mahal vermemek olabilir.

Yeniçerilerin desteği ile tahta çıkan Bayezid artık yaşlanmış ve gut hastalığı yüzünden sağlığ1 bozulmuştu. Büyük oğlu Ahmed'i tahta geçirmek istiyordu. Bu durumun farkına varan yeniçeriler ayaklanmışlardı. Selim'in tahta çıkmasını istiyorlardı ${ }^{25}$.

\section{Yavuz Sultan Selim Dönemi}

Bayezid'in büyük oğlu Şehenşah ve ikinci oğlu Korkud hayatta oldukları halde, kendisinin yerine geçmek üzere seçtiği Şehzadesi Ahmed uzun zamandan beri kurduğu planı uygulamaya koymak için Ali Paşa'nın hezimetinden sonra 0egbüze civarına kadar payitahta yaklaşmıştı. Hersek Ahmed Paşa ki Ali Paşa'nın vefatı üzerine üçüncü defa olarak vezir-i azamlık makamına getirilmişti fakat Yeniçerilerin Selim taraftarı olduklarını açıktan açığa ilan etmelerine mani olamadı; Yeniçeriler Anadolu'da Osmanlı ordularının son defa uğradıkları yenilgilerin sorumlusu olarak Ahmed'i ilan etmişlerdi. Selim'in denenmiş kahramanlığı sayesinde asker, itibarlarını iade edeceklerini ümit ediyorlardı. Bundan dolayı, Bayezid'in Aleksandr Borjiya nezdinde vaktiyle elçisi olan, ikinci vezir Mustafa Paşa'nın Şehzade Ahmed'i padişah olmak için Üsküdar'a gitmeye hazırladığı haber alınınca, istanbul'da isyan koptu (11 Ağustos 1511). Geceleyin, Yeniçeriler Mustafa'nın sarayını yağma ettiler. Mustafa yeniçerilerin elinden güç kurtulabildi. Daha sonra vezir-i azam sarayına gittiler. Ahmed Paşa soğukkanlı hareket ederek ve altın dağıtarak askeri sakinleştirmeye çalıştı. Fakat vezir Hasan Paşa'nın, Anadolu kazaskeri Müeyyed-zade'nin, nişancı Ca'fer Çelebi'nin ki üçü de Ahmed'e taraftar olmak üzere hazır idiler ve hanelerini yağmadan kurtarmaya çare bulunamadı. Avrupalı ve özellikle Floransalı tacirlerin mağazaları da tahribattan nasibini almıştır. Bayezid, isyanın büyümesinden korkarak vezir-i Azam’ın yerine Mustafa Paşa'yı, kazaskerin yerine Molla Halil'i, nişancının yerine Çandarlı Hanedanından son vezir-i azam İbrahim Paşazade'yi tayin etti ${ }^{26}$. Bayezid 30 yıl, 11 ay, 2 gün süren bir saltanattan sonra yine yeniçerilerin baskısıyla 24 Nisan 1512'de tahttan çekilmiştir ${ }^{27}$ Çünkü daha önce kendisi de yeniçeri desteği ile tahta çıktığı için durumu kabullenmiştir. 1512 yılında Yavuz Sultan Selim tahta çıkmıştır.

Yavuz, 23 Ağustos 1514 Çaldıran Zaferi sonrasında sonrasında bölgede bir süre kalarak Şiîlik ve Şah İsmail meselesini kesin bir çözüme kavuşturmak istiyordu. Nitekim Tebriz'de 9 gün kaldı. Buradan ayrılıp Anadolu'ya dönmek için Nahcivan'a gelindiğinde asker yiyecek ve giyecek sıkıntısından şikâyet etmeye başlamış durum iyice zorlaşmıştı. Yavuz Sultan Selim tüm

24 I. Hakkı Uzunçarşıll, Osmanlı Tarihi II. Cilt, 12. Bölüm, ATAM,ss. 161-179,2019, Ankara

25 Şerafettin Turan, II.Bayezid, TDV İslam Ansiklopedisi, 5. Cilt, s.234-237, 1992, İstanbul

26 Joseph Von,Hammer, Büyük Osmanlı Tarihi, Üçdal Neşriyat,C,4,s,92,Ankara,2003

27 Şerafettin Turan, II.Bayezid, TDV İslam Ansiklopedisi, 5. Cilt, s.234-237, 1992, İstanbul 
bu sıkıntılardan bıkmış 22 Eylül 1514 tarihinde Mustafa Paşa'dan boşalan vezirliğe Pîrî Mehmed Paşa'yı atamıştır. Pîrî Mehmed Paşa Yavuz Sultan Selim'in fikirlerine önem verdiği ölümüne kadar da görevde bıraktığı bir devlet adamı özelliğine sahip olmuştur. Bu atamadan sonra Pîrî Mehmed Paşa 'nın çabalarıyla Bayburt yöresinden sağlanan erzak ile kısa sürede askerlerin yiyecek ihtiyacını karşılanmış ve Yavuz Amasya'ya doğru yola çıkmıştır. Yavuz'un Amasya' daki saraya yerleştikten sonra Hersekzâde'den boşalan sadrazamlığa Dukakinoğlu Ahmed Paşa'yı getirmesi devşirme devlet adamları ve yeniçeriler arasında tedirginliğe sebep olmuştur. Devşirme devlet adamlarınca kışkırtılan bazı yeniçeriler 22 Nisan 1515 gecesinde Pîrî Mehmed Paşa ile padişahın hocası Hilmi Çelebi'nin kaldığı evlere zarar verdiler. Her ikisi de şans eseri bu saldırılardan kurtuldular. Bu durum karşısında Yavuz İstanbul'a dönünce bunu yapanları cezalandırmak üzere soruşturmalara başladı. Bazı yeniçeri ileri gelenlerini toplayarak şöyle dedi: "Pîrî Paşa ile Hilmi Çelebi'nin evlerini yağma edenler kimlerin tahriki iledir? Elbette bana bildirmek zorundasinız."

Soruşturma neticesinde suçlu olduğu kanaatine varılan Vezir İskender Paşa ve Sekbanbaşı Balyemez Osman Ağa tutuklanıp hemen idam edildiler ${ }^{28}$. Yavuz'un değer verdiği bu iki şahsiyetin seçilmesi manidardır. Bu saldırıyı düzenleyenlerin durumdan ne kadar rahatsız oldukları ve sonucunu az çok tahmin ederek neler yapabilecekleri görülmektedir.

1517 yılında Yavuz Sultan Selim'in fethettiği Mısır' da, yönetimin içişlerinde bağımsız olması sebebiyle, durum önceleri farklıydı yeniçeriler maaşlarını İstanbul ve diğer Osmanlı vilayetlerindeki yeniçerilerden farklı olarak " memlûk hünkârlar” gibi alırlardı. Fakat 27 Ekim 1522 tarihinde Vezir Mustafa Paşa'nın Mısır Valisi olmasından sonra değişen ülke yönetiminin sonucu olarak yeniçeri maaşları Osmanlı düzenine göre ödenmiştir ${ }^{29}$.

Yeniçeri ordusu birbirine sıkı bir şekilde bağlı güçlü, ayrıcalıklı ve dışa kapalı bir kurumdu. Başlangıçta yeniçeriler Hıristiyan esir ve kölelerden devşirme yoluyla seçilirlerdi. Kuruluşundan itibaren Bektaşilik tarikatıyla bağı olan Yeniçerilerin aileleri arkadaşları kışlaları da evleriydi. Yeniçeriler evlenmeleri yasaktı. Yalnızca yeniçeri subayları, garnizon işlerinde çalışan yaşlı askerler ya da emekli olanlar evlenebilirdi. Yeniçeri Talimatnamesi anlamına gelen Kavanin- $i$ Yeniçeriyan' da bu konu şöyle anlatılmıştır;

“Çok eskilerden beri, Yeniçerilerin evlenmeleri yasaktır. Sultan'ın izniyle yalnız subaylar ve askerlik için yaşlanmış erler evlenebilirler. Yeniçeriler cinsel perhiz yaptıklarından kendileri için yapılmış kışlalarda yaşarlar."

Yukarıdaki bilgilere ek olarak Yeniçerilerin askerlik dışında başka bir işte çalıştırılmayıp emekli olana kadar evlenemedikleri ve esnaflık yapamadıkları ile ilgili birçok kaynakta bilgiler yer almaktadır. Bu bilgileri doğrulamak adına yaşanan bir hadise şöyledir; Kanuni Sultan Süleyman'ın Zigetvar seferi sırasında bindiği atın gemi kırılmış ve bu aleti bir yeniçeri tamir etmiştir. Padişah bunu duyunca ordu içine esnaf karıştırılamayacağını belirterek, ilgili yeniçeriye ulûfesini vererek emekli ettirmiştir ${ }^{30}$.

28 Ramazan ATA, ASED | Aksaray Üniversitesi Sosyal Bilimler Enstitüsü Dergisi, 2020 (Aralık) / Cilt:4, s. 233-234 / Say1:2 I S.S 227-240

29 Nikolay İvanov, Osmanlı’nın Arap Ülkelerini Fethi, Türk Tarih Kurumu, s.55-56, 2013, Ankara

30 Cafer Çiftçi, Osmanlı Taşrasında Yeniçerilerin Varlığı ve Askerlik Dışı Faaliyetleri, OTAM, s. 37, 2010, Bursa 


\section{Kanuni Sultan Süleyman Dönemi}

Kanuni Sultan Süleyman döneminde Yeniçeriliğin satın alma ve miras yoluyla geçmesi uygulaması yaygınlaşmıştır. Zamanla büyük çoğunluğu da evlenmiş ve ordunun çöküşünü başlatmıştır ${ }^{31}$.

XVII. yüzyılda devlet sadece taşrada değil merkezde de bazı sorunlarla yüzleşti. Özellikle mutlak iktidara sahip hükümdarlık anlayışı gitmiş yerine seferlere katılmayan, iktidarını hane halkına devretmeyi tercih eden bir yönetim anlayışı oluştu. Bu durumlar özellikle Kanuni Süleyman döneminde yaşanmıştır. Padişah Kanuni Sultan Süleyman, kendi kız kardeşleri ve kızlarını dokuz sadrazamını ile evlendirdi. Böylelikle iktidara yakın olan ve güç sahibi aileler meydana gelmiş, neticesinde saray içerisinde farklı siyasal görüşler oluşmuş ve çatışmalar başlamıştır. 1660'lı yıllarda artık iktidar bir nevi hırsla ve entrikalarla yönetimi ele geçiren saray içi oligarşiye bırakılmıştır. $\mathrm{Bu}$ duruma paralel olarak yeniçeri-padişah ilişkileri de eskisi gibi olmamıştır. Yeniçerilerin padişaha bağlılıkları sadece sözde kalmış ve uygulamada saray çevresinde oluşan yeni farklı gruplarla ittifaklar kurarak padişaha isteklerini kabul ettirmeye başlamışlardır. Yeniçeri Ordusunun padişah ve saray çevresinde baskı oluşturmalarının tek sebebi otoritenin ya da merkezî idarenin zayıflaması değildir. Nitekim XVI. yüzyılın sonunda baş gösteren ekonomik buhranın neticesinde gelirleri azalan yeniçeriler askerlik mesleğine ek olarak esnaflığa dâhil olmaya başladılar ve esnaf loncaları ile aralarındaki bağı kuvvetlendirdiler. Artan vergiler karşısında ezilen esnaf örgütleri ile yeniçerilerin ittifak kurmaları esnafın şikâyetlerini merkeze duyurabilmek için en iyi yol olarak gözükmektedir ${ }^{32}$.

\subsection{Yeniçeri'den Kanuni Sultan Süleyman İle Rüstem Paşa’ya Mektup}

Kanuni Sultan Süleyman hükümdar olduğu 1520 tarihinden itibaren doğu ve batı seferlerinde ordusunun başında seferler yapan ordularının üzerinde büyük bir otoriteye sahip olan bir hükümdardı. Ancak otuz dördüncü senesinde artık sefere çıkamıyordu. 1553 yılında da kapıkulu ocaklarını vezir-i azam Rüstem Paşa'nın sorumluluğuna vermiştir.

Sultan Süleyman'ın büyüğü Amasya valisi Mustafa olmak üzere, Selim, Bayezid, Cihangir adlarında dört oğlu vardı. Bunlardan büyük şehzade olan Mustafa, tahsilli, yeniçeriler tarafından sevilen ve saltanata talip bir şehzade özelliklerine sahip olmuştur. Bu dönemde Fatih Sultan Mehmed'in düzenlediği saltanata geçen evladın kardeşlerini öldürmesi kanunu geçerliydi bu yüzden padişah yaş aldıkça elde bir veraset kanunu olmaması sebebiyle şehzadelerde de kayg1 artıyordu. Diğer yandan Bayezid'in annesi olan Hürrem Sultan ise oğlunun hükümdar olmasını istiyordu, bunun için damadı vezir-i azam Rüstem Paşa ile zevcesi Mihrimah Sultan ile annesi ayrı olan büyük şehzade Mustafa'nın ortadan kalkması hususunda birlikte hareket ediyorlardı.

Şöyle ki Rüstem Paşa, şehzade Mustafa’nın imzasını taklit ederek onun İran Şahı Tahmasb ile dost gösterecek mektuplar uydurmuştur. Bunu haber alan Şehzade Mustafa da bazı valilere mektuplar yollamış kendisine taraftar aramıştır. Daha sonraları yeniçeriler de Şehzade Mustafa'nın yanında yer almışlardır.

31 Bernard Lewis,Ortadoğu, Arkadaş Yayınevi, s.159-160, 2014, Ankara

32 Ahmet Elibol, Yeniçeriler ve İktidar Bağlamında Osmanlı Sisteminin Dönüşümü, Akademik Bakış Cilt 3,s.30-31, Sayı 5 Kış 2009, Ankara 
1553 'de Vezir-i azam Rüstem Paşa kapıkulu ocaklarıyla İran seferine çıktığı sırada, Konya Aksaray'ına gelmiş, burada casusları aracılığıyla yeniçerilerin padişahı Dimetoka'da oturtup Amasya valisi şehzade Mustafa'yı hükümdar ilan edeceklerini öğrenmiștir. Derhal durumu padişaha bildirmek üzere, sipahiler ağası Şemsi Ağa ile Çavuşbaşı'nı İstanbul'a yollayarak padişahın, bizzat askerin başında sefere çıkmasının uygun olacağını arz etmiştir.

Bunu öğrenen Sultan Süleyman bizzat sefere çıkarak kendisinin, ordunun başında sefere gidecek güce sahip olduğunu göstermiştir. Padişah Karaman Ereğlisi'ne geldiğinde Amasya valisi Şehzade Mustafa babasının elini öpmek için otağ-1 hümayuna gelmiş fakat önceden planlandığı şekilde padişahı görememiş ve boğulmak suretiyle öldürülmüştür. Yeniçerilerin padişah olarak görmek istedikleri Şehzade Mustafa'nın bu şekilde ölümü yeniçeriler arasında kabul edilememiş ümitlerini söndürmüştür. Yine de padişaha karşı ses çıkaramamışlardır. Padişah da onları yatıştırmak için ikinci vezir Kara Ahmed Paşa'yı vezir-i azam yaparak bu işte rolü olan Rüstem Paşa'yı azletmiştir.

Hürrem Sultan’la kızı Mihrimah Sultan, padişahı doldurmuş ve Rüstem Paşa'yı tekrar sadarete getirmek için Kara Ahmed Paşa'nın idamına sebep olarak Rüstem Paşa'yı tekrar vezir-i azam makamına tayin ettirmişlerdir (1555). Rüstem Paşanın bu ikinci sadareti yeniçeri ocağını iyice sıkmıştır.

Bu durumdan hoşnut olmayan yeniçeriler padişaha ve vezir-i azam Rüstem Paşa ile ikinci vezir Semiz Ali Paşa'ya mektuplar ile kendilerini ifade etmişlerdir (1558 M.). Yeniçerilerin, bu mektuplardaki şikayetlerine ve tehditlerine rağmen Rüstem Paşa'nın ölümünü müteakip olarak ağaları, 1561' de Beylerbeyliğine (iki tuğlu paşalığa) nakledilmek yani terfi etmek suretiyle değişmiştir. Bahsi geçen mektup örnekleri aşağıda eklenmiştir. Padişaha hakaret içeren ağır mektuplardır. İfadelerde Şehzade Mustafa'ya taraftar oldukları açıkça görülmektedir. O zamana kadar yeniçeriler isteklerini ağaları veya vezirler aracılığıyla padişaha arz ederlerken öfkelerinden dolayı mektuplar vasıtasıyla bizzat padişaha hitap etmek suretiyle takdim etmişlerdir. $\mathrm{Bu}$ mektuplardan anlaşıldığına göre önce dolaylı olarak şikayetlerini yapmışlar ve başarılı olmayınca mektup yoluyla tehdide kalkışmışlardır.

Yeniçerilerin mektuplarının özü ağalarından şikayetlerini içermektedir. Yeniçeri ocağının kuruluşundan itibaren şimdiki ağaları gibi zalim bir ağanın gelmediği ve bu ağanın tecrübeli bölük başlarını birer bahane ile Erzurum'a kalelere gönderdiğini, gidenlerin bir kısmının İran'a kaçarak orada tüfek adedinin arttığını, babası Sultan Selim'in kul ahvaliyle bizzat meşgul olduğunu, hâlbuki şimdi padişahın bir alay zalime itimat ederek kendilerinin şikâyetlerini dinlemediğini, henüz ağzında domuz eti kokan macarı (yani ağalarını) başlarına getirdiğinden saymakla bitmeyecek bu hallerden dolayı bıçağın kemiğe dayandığını bu sebepten şerrinden kurtulmak için fesat çıkarıp kan döküleceğini ve bu hale de kendisinin (padişahın) sebep olacağını arz ettikten sonra: "Sözün doğrusunu söyleriz, senden dahi oğullarından dahi ve paşalarından dahi bizar olduk; bir fesad ederiz ki Mustafa Ağa zamanında 8 olan fesad bunun zerresi ola nolaydı; Sultan Mustafa ölmekten biz kırılaydık. Senden sonra bu oğulların dahi senin yerine gelip anların zamanında bir acemi gavurdan gelmiş huyu, suyu bilinmez oğlan gelip ağa olup bize nahak böyle eza ve ceza ede, hor ve hakir olavuz."

"Ne devletsüz başımız var imiş ki Sultan Mustafa gidip biz kalmak" deyip ve "Sultan Mustafa sağ olsa idi, iş başka türlü olurdu." diyerek sonunda da "bu macar gavurunu tepelemek işten bile 
değilse de padişah'ın şeref ve haysiyetinin muhafazası için keyfiyeti arz eylediklerini ve sofu diye itimad ettiği ăganın yalıda kaç meyhane ihdas ettiğini teftiş ettirmesi" konusunu da şikayetlerine eklemişlerdir.

\subsection{Yeniçerilerin Mektuplarının Sureti}

"Devletlû hünkarın ayağı toprağına yeniçeri kullarının arzıhali budur ki...

Haliya ăgamız olan kimesnenin elinden aciz ve fermande (fürûmânde) kaldık. Al-i Osman peyda olalu ve yeniçeri, yeniçeri olalu böyle zalim, böyle haramzade müfsid, suret uğrusu şeytan sofusu azyemez ağa ne gelmiştir ve ne gelecektir; bunun zamanında yeniçeri olmaktan gavur olmak yeğdir.

Devletlu Padişah! sen bunu adam sanursın; bu adam değildir; bu şeytan aleyhüllane kendusidir. Hayf yazdik, senin buna ittüğin itikada. Haşa ve kella bu, senin terbiyende büyümüşs ola. Yazuk değil midir? Ne hak bilür ne şeriat bilür bir zalim müfsiddir kanden geldi? Evvela her kim bunu ortaya getürüb ağa olmasına sebep olduysa Tanrı rahmetinden mahrum ola. Gün olur mu ki seni mazlemeye koymıya. Bigünah bunca kişinin dirliğine mani olup ve nice kimesnenin dahi katline sebep olur; ahrette bunun cevabı senden mi talep olunur, yoksa kendusinden mi? Niçin görmezsin, Padişah-ı alem-penahsın, hak katında ne cevap vereceksin? Kendu sikarı (şikarı) kande bir oğlan var ise ileru çeküb yaban oğlanlarına yayabaşıllk ve bölük başıllk virüb, kande bir ihtiyar var ise bir bahane ile ya Erzurum hisarına veya dizdarlığına çıkarur oldu; atan ve deden zamanında yeniçeri kullarının bir günahı oldukta Rumelinden gayrı yere çıkarmazlardı; bu ağanın zamanında Erzurum'a gider oldu, kızılbaşa gitmesi kolay olsun. Teftiş eylen, görürsiz. Bu ağa zamanında ulûfesi kesilen yeniçerilerin kaçı kızılbaşa çıkıp gitmiştir. Elhamdülillah İslam Padişahısın, her ne yire ki kasd etsen elün yeter. Bu mel'un, ağa olmazdan evvel kızılbaş ne miktar tüfenklüye kadir idi, şimdi ne kadar tüfenklisi vardır kutlu olsun. Sancak beylerinde şimdüye değin pek yok idi. Bu ağa zamanında gidilere dahi sancak verilür oldu; kuyumcu Kasım ki kendüye üskufler ve kemerler işlemekle. Bunca kullarun var ki kimi atan ve deden kuludur. Ol zamandan beru taş yasdanub toprak döşenüb hizmette dururlar, anlara ancak müyesser olmaz, kuyumcu Kasım gibi kızı sohbette gidilikle meşhur iken ana sancak alıverirsin. Gafilsin. Bu mel'unun kangi fesadını ve kangi kabahatini idelüm, feemma ol hacetimiz değildir, ancak canumuz acıdığından söylerüz. Bizim günahımız nedir ki bu macar kafiri ki dün gavurdan gelmiş, henüz tomuz eti ağzında koka duruyor ıo, bize havale idesin. Nahak ırzımızı ve namusumuzu paymal edip türlü türlü hakaretler itler, eğer günahımız var ise kendu elinle bizi öldür, bir uğurdan kurtulalum.

Adil Padişah oğlusun. Atan kimesneye itimad etmezdi, kulun ahvalini kendi görürdü. Sen bir alay zalime itimad edüb irha-i inan etmişsin, anların ise eksükleri değildir, her kangisine vamp halimizi ağlasavuz "ben bilmezim ol ağanuzdur, ol bilür" deyu cevap ederler. Ya biz halimizi kime ağlayalum, elhasıl sabır ve takat kalmadı. Bıçak söküğe erdi, gayetle canumuz acıduğundan sana arzıhal-ı itdük. Ya bu zalimi bizden gider bizi bunun şerrinden halas eyle yahut bir külli fesad ederiz, nice can telef olup nice Müslümanın rızkı zayi ola, ırz ve namusa halel geldüğinden gayrı hak katında dahi mes'ul olursun, vebali boynuna. Elhasıl sözün doğrusunu söylerüz. Senden dahi ve oğullarından dahi ve paşalarundan dahi bizar olduk. Bir fesad iderüz ki Mustafa Ăga zamanında olan fesad bunun zerresi ola nolaydı. Sultan Mustafa ölmekten biz kırılaydık. Senden sonra bu oğulların dahi senin yirüne gelüb anların zamanında böyle bir acemi gavurdan gelmiş hudu sütlü bilmez oğlan gelib ağa olub bize nahak böyle eza ve ceza idib hor ve hakir olsavuz gerek. Hem ahır ömründür 11, Allah' tan kork, bizim halimizi gör. Adam kıtluğı değildir, bu haramzadeyi üzerimizden gider, şerrin def eyle ve illa olacağını biz dedik, sonra günah bizden değildir ve bu hususta bir mufassal kağıt dahi Rüstem Paşa'ya ve Ali Paşa 'yal2 atub dururuz, anları göresiz. Vay bize ne devletsüz başımız var imiş ki Sultan Mustafa gidüb biz kalmak. Bari ol sağ imişse, iş bir türlü dahi olurdu. Evvela bu bizüm çekdüğimiz nedir? Buna kim katlanur. Her gece odaya geldüğimizce koyun bıçağa gider gibi ardumuza bakup dururuz ki bu gece kimin beratı gelür deyu. Gel Devletlu Padişah nola 
Padişah oldun ise hele bu kulların halin dahi insaf eyliye. Böyle bir zalimi havale eyleyip hor ve hakir ettirmek olmaz. Bu miskinlerin içinde nice emekdarlarun vardır, bize dahi hayf değil midir? Sen esirgemezsen ya bizi kim esirgesün. İleru zaman yeniçerileri gibi şarabta, avratta ve oğlanda değilüz, kavga ve galebede değilüz, beş vakit namazımızda ve hayır duanızdayüz, belki fesad ve şenaat eden yine bir kaç dinar vermekle eyü olur; biz mücrim ve günahkar oluruz. Vallahilazim adımız yeniçeridir. Şare (şehre) pazara çıkamazız. Bu ağanın zamanında şöyle hor ve hakir olduk ki şartla ve pazarda at oğlanı bizi döğer oldu, korkumuzdan kimesneye söyleyemez olduk. Allah 'tan reva mıdır? Geçende kenduye bir kağıt yazub atduk, bulayki insafa gele deyu. Ezayı ve cefayı dahi ziyade etmeğe başladı, meğer senin rızan var ola ki böyle itler. Eğer senin dahi rızan var ise malum oldu ki açıkla (açıkca) bu taife bir fesad ettikleri ister imişsin? Bunu dahi fehmetmez misin ki bunun körlügüüne şehre od atalar, son nedamet faide etmez mi? Bu ezaya biz mütehammil olmayub bu macar gavurun çoktan hakaretle depeler idük, lakin senin ırzını sakınıb yolundan sana arz itdük, eğer giderdik kavgayı def itdük hoş ve illa olan fesadın ve fitnenin vebali boynuna olur bilmiş olasin. Dahi durub bakmak olmaz, vallah vallahi fesad ideriz onat âgâh ve haberdar olasin. Sayirlerde şaraba yasă̆ idersin, sofu deyû itimad ettiğün ağa yalıda kaç meyhane ihdas etmiştir teftiş eylen göresiz". ${ }^{33}$

Yeniçeri Ocağı'nın düzeltilmesi sorunu 17. yüzyılın başlarında beri çözülememişti ve 18 . yüzyılın sonlarında her zamanki gibi sorun olarak duruyordu. Sultan III. Selim, modernleşme taraftarı, yenilikçi, aydınlıkçı ve ileri fikirleri benimseyen Padişahdı. Padişah olarak ilk icraatı iktisadi kalkınma hedefi doğrultusunda Avrupai orduyu kurma teşebbüslerini hedef almıştı. Kamusal alanda özellikle maliyeyi, yargı üzerinde modernleşme hareketleri ve milletin eğitim ve fikri seviyesini yükseltecek uygulamalar ile planları faaliyete geçirmiştir. Sultan III. Selim, modern bir ordu istemesi malum darbe olsa da Yeniçeri Ocağı'nın eğitim ve talimi yapmak istememesi, "talim gavur işidir" sözleriyle fetva veren ulemanın, Ocağın olumsuz tutumlarına destek vermesi gibi nedenlerdir. Artık Ocağın ıslah olması mümkün değildir ${ }^{34}$. Yeniçeriler dışında isyanlarda rolü bulunan diğer gruplar ulema zümresi ve tarikat ehlidir ${ }^{35}$.

\section{Sonuç}

Osmanlı devleti kuruluşundan itibaren orduya ve ordu düzenine önem vermiş gerileme dönemine kadar sürekli ordusunu güçlendirmeye ve dönemin şartları ile donatmaya çalışmıştır. Kuruluş döneminde Osmanlı ordusu, Kendi kayı boyu yiğitlerinden ve Osmanoğulları'na biat etmiş diğer Türkmen boylarının yiğitlerinden meydana geliyordu. Orhan Bey döneminden sonra savaş esirlerinin asker olarak kullanılmasına başlanmıştı. Bu dönemde yine para ile satın alınan esirlerden de askerler devşirilmeye başlanmıştı. Fakat bu askerler ile ilgili tam bir kanunname ve nizam olmadığı birçok tarihçi tarafindan belirtilmiştir.

II. Murad döneminde Acemiler Ocağı kurularak bu yeni askerlerin eğitimi ve disiplini için önemli bir adım atılmıştı. Aslında yeniçeri ocağına insan kaynağı olan devşirme usulü Fatih Sultan Mehmed döneminde tam sistematik hale gelmiştir, diyebiliriz. Fatih Sultan Mehmet Döneminde

33 I. Hakkı Uzunçarşılı, , "Şehzade Mustafa`nın Ölümünde Medhalı Olan Vezır-I Azam Rüstem Paşa’nın Ikıncı Sadaretınde Yenıçerılerın Ağalarından Şıkayetı Havı Kanunı Sultan Süleyman Ile Rüstem Paşaıya Pek Ağır Mektupları", Belleten, Cilt: XXXI - Sayl: 122 - Nisan, ss,192-199, 1967, Ankara

34 Deniz,a.g.e,2019,s,7147

35 Yunus İnce,(2018). Sultanın İsyankâr Kullarının İlk İsyanı: Buçuktepe Vakası (1446). History Studies, 10(5), 83 - 101. Doi: 10.9737/hist.2018.62,s,92 
Hristiyan çocukların devşirilmesiyle başlayan sistem 18. Yüzyılın ortalarına kadar devam etmiştir. Genelde Hristiyan köylü çocuklarının içinden sağlıklı olanlar seçilirdi. Şehirde yaşayanlar, babası bir süreliğine bile olsa devlet görevinde bulunanlar, Türkçe bilenler, şehir görmüş çocuklar ve Yahudi tüccarların çocukları alınmazdı. Çünkü bu çocukların gözlerinin açıldığı ve istenildiği eğitilmeyeceği düşünülürdü. Rumeli'den alınan çocuklar Anadolu'ya, Anadolu'dan alınan çocuklar Rumeli'ye gönderilirlerdi ki, çocuklar kolaylıkla kaçıp köylerine dönmesinler diye. Devşirilen bu çocukların devlete ve hanedana sadakatini sağlamak için öncelikle Müslüman Türk ailelerin yanına verilirlerdi; böylece İslam dinini ve Türk gelenek ve göreneklerini öğrenmeleri sağlanırdı. Bu çocuklar ailedeki eğitimi aldıktan sonra önce Acemi Oğlanlar Ocağına daha sonra düzenlenen bir törende gösterdikleri hünerler doğrultusunda yeniçeri ağası tarafindan Yeniçeri Ocağına seçilirlerdi. Bu uygulama ile aslında en iyilerin bir üst ocağa seçilmesine imkan verilmiş bir anlamda askerin kendini geliştirmesine firsat tanımak için bir rekabet ortamı oluşturulmuştur.

Yeniçeri İsyanları ve devletin siyasal işleyişine müdahaleleri Fatih Sultan Mehmet tahta geçmek üzereyken çıkartılan Buçuktepe isyanıyla başlamıştı. Daha sonraları Bayezid'in, Yavuz Sultan Selim' in tahta çıkmalarında hep yeniçeriler etkili olmuştur. Yeniçerilerin padişah değişstirecek kadar güçlenmesi devlet adamları arasında da rekabetlere ve yeniçeri ocaklarının farklı Paşaları tutmalarına neden olmuştur ki böyle bir rekabet devletin merkezi otoritesini zayıflatmıştır.

Yeniçeriler her zaman Osmanlı ordusunun en önemli unsuru olmuştur. Uzun bir süre hem maddi anlamda hem de manevi anlamda doyum yaşayan yeniçeriler bütün odaklanmalarını savaşlara ve devletin varlığına vermişlerdir. iyi maaş alan bunun yanı sıra padişahlardan cülus bahşişi alan ve ganimetlerden pay alan yeniçerilerin maddi sıkıntıları olmamıştır (Gerileme Dönemine kadar). Manevi olarak ise kendilerini Nefer-i Bektaşiyan olarak tanımladıklarından dolayı Bektaşilik ruhani kılavuzları olmuştur.

Kanuni Sultan Süleyman döneminden sonra fetihlerin durma noktasına gelmesi ve hazinenin zayıflamaya başlamasından dolayı yeniçeriler çoğu zaman kazan kaldırarak ulufelerinin arttırılmasını talep etmişlerdir. Devlet içinde siyasi olarak da güçlenen yeniçeriler devlet adamlarının değiştirilmesinde ya da katledilmesinde etkin rol oynamışlardır. Gün geçtikçe yeniçeri ocağında görülen disiplinsizlikler, askerlikle ilgisi olmayan esnafın bile sırf maaş alabilmek için yeniçeri ocağına kayıt olmaları bozulmanın ne derece olduğunu göstermekteydi.

Osmanlı devletinde ilk kez yeniçeri ocağını genç Osman kaldırarak yerine daha disiplinli ve çağın gerekliliklerine daha uygun bir ordu kurmak istemişti fakat bunu haber alan yeniçeriler ayaklanarak yeniçeri ocağının kaldırılmasını engellemiş ve padişah genç Osman'ı katletmişlerdi. Daha sonra gelen Osmanlı padişahları da orduda batılı anlamda yenilikler yapmaya çaba gösterdiler. Sultan III. Selim zamanında Nizam-I Cedid ordusu kurulmuştu fakat yeniçeri ordusunun çıkardığı Kabakçı Mustafa isyanı ile bu orduya da son verildi. Çünkü yeniçeriler kendilerine alternatif bir gücün var olmasını istemiyorlardı.

Nihayet, Sultan II. Mahmud döneminde 15 Haziran 1826 yılında yeniçeri ocağı kaldırıldı. Yeniçeri Ocağının yerine daha modern olan Asakir-i Mansure-i Muhammediye ordusu kurulması devleti iç ve dış güvenlik konusunda rahatlatmıştır. 


\section{Kaynakça}

Akdağ, Mustafa. «Yeniçeri Nizamının Bozulması.» Ankara Üniversitesi DTCF Dergisi V, no. 3 (1947): 291-322.

Ata, Ramazan. "Vefatının 500. Yılında Yavuz Sultan Selim ve Camalî Ailesi ile Münasebetleri.» Aksaray Üniversitesi Sosyal Bilimler Enstitüsü Dergisi 4, no. 2 (2020): 227-240.

Başkan, Yahya. «Osmanlı'da Çıkan İsyanların Öncüsü: "Fatih Sultan Mehmed Dönemi Yeniçeri İsyanları”.» Osmanlı Payitahtında Siyasi Muhalefet Ve Protesto Kültürü içinde, yazan Yasem Avcı ve vd. İstanbul: Libra Kitapçılık Ve Yayınları, 2020.

Beydilli, Kemal. «Yeniçeri.» TDV Íslam Ansiklopedisi 43 (2013): 450-462.

Çiftçi, Cafer. «Osmanlı Taşrasında Yeniçerilerin Varlığı Ve Askerlik Dışı Faaliyetleri.» OTAM, no. 27 (2010): 27-57.

Demir, Abdullah. «Osmanlı Devlet'inde Devşirme Sistemi.»Uluslararası Sosyal Bilimler Dergisi I, no. 1 (2017): 19-27.

Deniz, Ahmet. «Osmanlı Devletinde Yaşanan darbe Ve İsyanların İktisadi Açıdan Analizi.» Social Science Journal, no. 5 (2019): 7146-7147.

Elibol, Ahmet. «Yeniçeriler Ve İktidar Bağlamında Osmanlı Sisteminin Dönüşümü.» Akademik Bakış 3, no. 5 (2009): 30-31.

Hammer, Joseph Von. Büyük Osmanlı Tarihi. Cilt IV. Ankara: Üçdal Neşriyat, 2003.

İnalcık, Halil,Kuruluş Ve İmparatorlık Sürecinde Osmanlı. İstanbul: Timaş Yayınları, 2011.

İnce, Yunus. «Sultanın İsyankar Kullarının İlk İsyanı: Buçuktepe Vakası.» History Studies, 2018: 83-101.

İvannov, Nikolay. Osmanlı'nın Arap Ülkelerini Fethi. Ankara: TTK, 2013.

Katg1, İsmail. «Osmanlı Devleti’nde Tipik Bir Askeri Ayaklanma Örneği: Viyana’dan Dönüş ve 1687 İsyanı.» Vakanuvis Uluslararası Tarih Araştırmaları Dergisi 5, no. 2 (2020): 759-814.

Kaytaz, Fatma. «Osmanlı Askeri Teşkilatı Hakkında Bilinmeyen Bir Eser "Yeniçeri Ocağına İlişkin Bir Risale” (Değerlendirme Ve Metin.» Tarih Dergisi 0, no. 57 (2013): 45-68.

Lewis, Bernard. Ortadoğu. Ankara: Arkadaş Yayınevi, 2014.

Maden, Fahri. «Yeniçerilik-Bektaşilik İlişkileri Ve Yeniçeri İsyanlarında Bektaşiler.» Türk Kültürü Ve Hacı Bektaş Veli Araştırma Dergisi, no. 73 (2015): 173-202. 2008.

Ortaylı, İlber. Osmanlı'da Milletler Ve Diplomasi. İstanbul: İş Bankası Kültür Yayınları,

Özcan, Abdülkadir. «Buçuktepe Vak»ası.» TDV İslam Ansiklopedisi içinde, yazan TDV, 343-344. İstanbul, 1992.

Turan, Şerafettin. «II. Bayezid.» TDV Íslam Ansiklopedisi V (1992): 234-237.

Uzunçarşılı, İ.Hakkı. Osmanlı Tarihi. Cilt II. Ankara: ATAM, 2019.

Uzunçarşılı, İ.Hakkı. «Şehzade Mustafa’nın Ölümünde Medhali Olan Vezir-i Azam Rüstem 
Paşa'nın İkinci Sadaretinde Yeniçeri Ağalarından Şikayeti Havi Kanuni Sultan Süleyman İle Rüstem Paşa’ya Pek Ağır Mektuplar.» Belleten XXXI, no. 122 (1967): 192-199.

Ünal, Mehmet Ali. Osmanlı Müesseseleri Tarihi. Isparta: Fakülte Kitabevi, 2010.

Y1lmaz, Gülay. «Bektaşilik Ve İstanbul'daki Bektaşi Tekkeleri Üzerine Bir İnceleme.» Osmanlı araştırmaları Dergisi, 2015: 97-136.

Yüksel, Ahmet. «Yeniçeri Ocağı, Bozulma Ve casusluk.» Journal Of History Studies, 2017 : 271-296. 